\title{
PANDEMIA EBOLI JAKO ZAGROŻENIE DLA MIĘDZYNARODOWEGO POKOJU I BEZPIECZEŃSTWA: KWESTIA BEZPIECZEŃSTWA ZBIOROWEGO CZY ZARZĄDZANIA GLOBALNEGO?*
}

\section{WPROWADZENIE}

Ewolucja problematyki zdrowia publicznego na poziomie międzynarodowym skłoniła państwa do powołania międzynarodowej organizacji Światowej Organizacji Zdrowia (WHO), której misją jest „osiagnnięcie przez wszystkich ludzi najwyższego możliwego poziomu zdrowia”. W tym celu organizacja ta zobowiązana jest nieść pomoc i udzielać wsparcia, stymulować współpracę i badania naukowe oraz promować wszelkie działania mogace przyczynić się do postępu w ochronie zdrowia. W systemie Narodów Zjednoczonych WHO jest więc główną instytucją odpowiedzialną za ochronę zdrowia publicznego na poziomie międzynarodowym. Oznacza to, że zgodnie z zasadą regulujacca kompetencje organizacji międzynarodowych jest instytucją wyspecjalizowana w tym obszarze działania. Taka jej funkcja wyrasta z przekonania, że „współpracę w sferze gospodarczej i społecznej najlepiej realizują wyspecjalizowane instytucje, związane z Organizacja Narodów Zjednoczonych. WHO dysponuje równocześnie dużą autonomia"1. W sporze o autonomię bądź zależność od ONZ autorzy definiujący rolę WHO zdają się przechylać w stronę autonomii tej organizacji, niezależnie od rodzaju kontroli sprawowanej przez ONZ nad ta, jak i podobnymi in-

* Publikacja powstała w ramach stażu naukowego sfinansowanego w drodze konkursu ze środków statutowych Wydziału Prawa i Administracji Uniwersytetu im Adama Mickiewicza w Poznaniu.

1 Światowa Organizacja Zdrowia, jako wyspecjalizowana agenda ONZ, jest pierwszą organizacja, której wiedza i kompetencje określone w statucie i posiadana osobowość prawna odpowiadają za zdrowie publiczne na płaszczyźnie międzynarodowej. To sprawia, że jest ona niezależna w tej materii od jakichkolwiek innych podmiotów prawa międzynarodowego. Jej cele społeczne jako organizacji rządowej stanowią podstawowy powód, dla którego została ustanowiona, jako odpowiadajacca potrzebom państw, które ją stworzyły. Państwa członkowskie postanowiły przekazać jej kompetencję techniczna, aby odpowiedzieć na oczekiwania wyspecjalizowanych administracji państw członkowskich, z którymi ściśle współpracuje. Podobnie jak inne wyspecjalizowane agencje ONZ, WHO jest czasami uznawana za prawdziwą międzynarodową służbę publiczna, która doprowadziła do przyznania jej w niektórych przypadkach pierwotnych uprawnień decyzyjnych lub kontroli. Państwa członkowskie starają się jej nie upolityczniać. 
stytucjami, tzn. uznaja, że ONZ nie może im narzucać swoich rozwiązań, ponieważ „wyspecjalizowane agencje działają w systemie ONZ, a nie pod jej kierownictwem".

Światowa Organizacja Zdrowia odgrywa współcześnie szczególnie istotną rolę w walce $\mathrm{z}$ różnego rodzaju epidemiami. Jedną z nich jest epidemia wirusa eboli. W walce z ta epidemią WHO podejmuje takie działania, jak: jak uzyskanie dostępu do chorych, diagnozowanie ich, skutecznie leczenie i znalezienie leku pozwalającego zwalczać wirusa, przy jednoczesnym poszanowaniu godności osoby ludzkiej i jej przekonań ${ }^{2}$. Epidemia wywołuje także pytania o charakterze ogólnym dotyczącym zdrowia publicznego, m.in. o stan sanitarny populacji, nawet w krajach bogatych, czy o równość w dostępie do opieki zdrowotnej. Tymczasem statut WHO uznaje, że „posiadanie najwyższego możliwego poziomu zdrowia jest jednym z podstawowych praw każdego człowieka"3.

Jednakże - jak określił to Komitet Praw Gospodarczych, Społecznych i Kulturalnych ${ }^{4}$ w Komentarzu Ogólnym nr 14 - skuteczność realizowania prawa do zdrowia wymaga interwencji władz publicznych, szczególnie w walce z chorobami. Odpowiedzialność ta spada na państwa, poprzez ich działania samodzielne lub we współpracy, i na instytucje międzynarodowe, w szczególności na WHO. Rozprzestrzenianie się wirusa i nierzadko irracjonalne lęki ${ }^{5}$, które ono wywołało, stopniowo zmieniały podejście do problemu. Lokalny kryzys zdrowotny, który mógł być opanowany przez WHO, stał się regionalnym, a nawet globalnym kryzysem wymagającym globalnej reakcji. Odpowiedzialność za to może ponosić wyłącznie ONZ, z którą WHO, jako wyspecjalizowaną agencja, musi „ustanowić i utrzymywać efektywną współpracę”, a na jej żądanie powinna „udzielić lub pomóc w udzieleniu wsparcia i pomocy"6. Zasada ta została zawarta w Rezolucji Rady Bezpieczeństwa nr 2177 z 18 września 2014 r., w której wyrażono przekonanie o istnieniu zagrożenia dla pokoju i bezpieczeństwa międzynarodowego wynikającego z epidemii eboli.

\footnotetext{
${ }^{2}$ Wirus ebola (lub gorączka krwotoczna ebola) to często śmiertelna choroba, która po raz pierwszy pojawiła się w 1976 r. jednocześnie w Demokratycznej Republice Konga i Sudanie. Wirus jest endemiczny w tych regionach, a od 2013 r. nastapił jego „wybuch” (zgodnie z terminem stosowanym przez WHO) w Afryce Zachodniej, zob. OMS, Feuille de route pour la riposte au virus Ebola, rapport de situation (21 novembre 2014).

${ }^{3}$ Potwierdza to art. 12 Międzynarodowego paktu praw gospodarczych, społecznych i kulturalnych, zgodnie z którym „zdrowie jest podstawowym prawem człowieka, niezbędnym do korzystania z innych praw człowieka”.

4 Zob. Observation générale no 14, UN Doc. E/EC.12/2000/4 (12 août 2000).

${ }^{5}$ Zob. Courrier international no 1250 (16-22 octobre 2014) 30-37.

${ }^{6}$ Relacje pomiędzy ONZ a wyspecjalizowanymi agencjami opierają się na postanowieniach Karty, umowach zawartych między nimi oraz praktyce. Porozumienia te sa następstwem postanowienia zawartego w art. 63 Karty, który nadaje Radzie Gospodarczej i Społecznej uprawnienia do zawierania umów z wyspecjalizowanymi agencjami, pod warunkiem zatwierdzenia przez Zgromadzenie Ogólne oraz w celu powiązania ich z ONZ.
} 


\section{REAKCJA SPOŁECZNOŚCI MIĘDZYNARODOWEJ NA ZAGROŻENIE DLA POKOJU I BEZPIECZEŃSTWA SPOWODOWANE EPIDEMIĄ}

W marcu 2014 r. WHO została powiadomiona o pierwszych ogniskach epidemii gorączki krwotocznej ebola, które pod koniec 2013 pojawiły się w Gwinei. Wobec szybkiego rozprzestrzeniania się zakażeń WHO musiała w sierpniu 2014 r. ogłosić, że jest to zdarzenie o charakterze nadzwyczajnym w obszarze zdrowia publicznego o międzynarodowym zasięgu (Międzynarodowe przepisy zdrowotne 2005) ${ }^{7}$. Odpowiedź ONZ na tę sytuację pojawiła się 8 lipca $2014 \mathrm{r}$. w oświadczeniu prasowym wydanym przez Biuro ONZ ds. Afryki Zachodniej, w którym członkowie Rady Bezpieczeństwa wyrazili poważne zaniepokojenie epidemią eboli w niektórych krajach Afryki Zachodniej i wezwali społeczność międzynarodową do pomocy w zapobieganiu jej rozprzestrzeniania się.

Od tego czasu reakcja Narodów Zjednoczonych na epidemię wirusa ebola będzie nakierowana na osiagnięcie dwóch celów: uzyskanie jak najszerszego konsensusu w kwestii podstaw i sposobu przeprowadzenia planowanych działań oraz - w obliczu rosnącego zagrożenia - znalezienie odpowiedniego instrumentu prawnego umożliwiającego międzynarodową mobilizację na dużą skalę. Wraz z Rezolucją nr 2176 z 15 września 2014 r. w sprawie ewentualnego odnowienia mandatu Misji Organizacji Narodów Zjednoczonych w Liberii (UNMIL) Rada oświadczyła jednoznacznie, że jest: „poważnie zaniepokojona ogromem epidemii eboli w Afryce Zachodniej, w szczególności w Liberii, Gwinei i Sierra Leone”, zwróciła ponadto uwagę, że na rządzie Liberii „ciąży główna odpowiedzialność za utrzymanie pokoju i stabilności”, a także za ochronę ludności cywilnej, odwołując się, choć w sposób zawoalowany, do pojęcia odpowiedzialności za ochronę.

Po ogłoszeniu pierwszej rezolucji pojawiły się kolejne elementy, które ustala pozycję Rady Bezpieczeństwa, a w ogólnym ujęciu - ONZ. Rada podkreśliła związek między epidemią a „trwałą stabilnościa” Liberii i wskazała elementy niezbędne do organizacji adekwatnej odpowiedzi: główna odpowiedzialność państw, rola organizacji regionalnych i subregionalnych (Unia Rzeki Mano, ECOWAS, Unia Afrykańska), kluczowe znaczenie współpracy międzynarodowej w zaspokajaniu zapotrzebowania na wykwalifikowany personel medyczny i odpowiedni sprzęt, mianowanie głównego koordynatora systemu Narodów Zjednoczonych ds. zwalczania wirusa ebola, czy wreszcie jasno wyrażona przez państwa wola powstrzymania epidemii w ich granicach. O ile jednak, przy okazji przedłużenia mandatu UNMIL Rada wspomniała o zagrożeniach, jakie ebola stwarza dla powodzenia misji w budowaniu pokoju w Liberii, o tyle nie umieściła w tym dokumencie żadnej wzmianki o istnieniu zagrożenia dla pokoju i bezpieczeństwa międzynarodowego ${ }^{8}$.

${ }^{7}$ Zob. G.L. Burci, J. Quirin, Ebola, WHO, and the United Nations: Convergence of Global Public Health and International Peace and Security (2014), 18 ASIL Insights.

8 Sekretarz generalny ONZ, który wyznaczył głównego koordynatora systemu Narodów Zjednoczonych ds. eboli i uruchomił mechanizm reagowania kryzysowego organizacji, otrzymał listy od prezydentów Liberii, Sierra Leone i Gwinei wzywające do „kompleksowej reakcji na epidemię 
Z kolei 19 września 2014 r., po przyjęciu przez Radę Bezpieczeństwa Rezolucji nr 2177 (2014), Zgromadzenie Ogólne ONZ przegłosowało rezolucję w sprawie środków majacych na celu powstrzymanie i zwalczenie epidemii eboli w Afryce Zachodniej. Sa one uzasadnione potrzebą „ograniczenia tego kryzysu w obszarze zdrowia publicznego z powodu poważnych konsekwencji humanitarnych, gospodarczych i społecznych, jakie może on spowodować”. Dokument odnosi się także do rezolucji 2176 (2014) i 2177 (2014) Rady Bezpieczeństwa i z zadowoleniem przyjmuje zamiar sekretarza generalnego powołania UNMEER. Konsensus głównych organów systemu Narodów Zjednoczonych w obliczu epidemii eboli został osiąnięty. Udało się go zbudować w warunkach i według formuł o dużym ciężarze gatunkowym. Rezolucja nr 2177 (2014) plasuje się w centrum części normatywnej systemu Narodów Zjednoczonych. Odzwierciedla ona także istnienie szerszego konsensusu, rozciagającego się na całą rodzinę Narodów Zjednoczonych.

\section{ZAGROŻENIE DLA MIĘDZYNARODOWEGO POKOJU I BEZPIECZEŃSTWA - PODSTAWA REZOLUCJI NR 2177 (2014)}

Na tym etapie Rada Bezpieczeństwa nie miała wyboru. Aby podjąć aktywne działania w walce z epidemią eboli, musiała polegać na postanowieniach Karty, która stanowi o jej kompetencjach, tj. na art. 24 ust. 1, nakładajacym na RB główną odpowiedzialność za utrzymanie międzynarodowego pokoju i bezpieczeństwa, i na art. 39, pozwalajacym jej działać w sytuacji zagrożenia lub naruszenia pokoju. W rezolucji brak natomiast wzmianki o rozdziale VII Karty i o innych artykułach, poza wspomnianymi 24 i 39; pojawia się tylko lapidarne sformułowanie, w którym „[ocenia się], że nadzwyczajna rozległość epidemii eboli w Afryce stanowi zagrożenie dla międzynarodowego pokoju i bezpieczeństwa"9.

Cechy charakterystyczne wirusa ebola oznaczaja, że zagrożenie rozprzestrzeni się w sposób oczywisty na sąsiednie państwa, a następnie w odległe rejony, czemu sprzyja wzrost przepływu ludności i wymiany międzynarodowej ${ }^{10}$.

wirusa ebola, w tym skoordynowanych działań międzynarodowych w celu jej zakończenia”; zob. UN Doc. S/2014/669 (29 août 2014); 17 września 2014 r. wysłał on przewodniczącemu Zgromadzenia Ogólnego i przewodniczącemu Rady Bezpieczeństwa identyczny list, w którym podkreślił wymiar bezpieczeństwa kryzysu wynikającego z epidemii. Dokument UN A/69/389-S/2014/679 (17 września 2014). Co najważniejsze, ogłosił zamiar natychmiastowego powołania Misji Organizacji Narodów Zjednoczonych ds. Reagowania na Ebolę.

${ }^{9}$ Według Rady Bezpieczeństwa zagrożenie to charakteryzuje się wirulencją nieporównywalną z występująca podczas zwykłej epidemii. Dotyka ono przede wszystkim społeczności niestabilnych państw będących w trakcie procesu budowania pokoju po latach konfliktów zbrojnych. Jest ono o tyle poważne, że dotychczasowe działania podejmowane w tym obszarze mogłyby zostać znacznie utrudnione lub nawet przerwane przez epidemię, a początek odzyskanej stabilizacji nadszarpnięty „niepokojami i napięciami społecznymi, pogarszaniem się klimatu politycznego i obniżeniem poczucia bezpieczeństwa”.

${ }^{10}$ Wiele państwa jest objętych tą rezolucją, w szczególności Nigeria, ale epidemia rozprzestrzenia się także na inne państwa afrykańskie, takie jak Mali. Poza Afryką chodzi również o ludzi, którzy zarazili się choroba, a następnie przenieśli się do Europy lub do Ameryki Północnej. 
W ten sposób kryzys zdrowotny w trzech państwach, ze względu na kontekst, może stać się zagrożeniem dla pokoju i bezpieczeństwa, a następnie przerodzić się w zagrożenie o zasięgu międzynarodowym. O ile zagrożenie wynikłe z kryzysu zdrowotnego przeszło w kryzys ekonomiczny, społeczny, polityczny, humanitarny i w końcu bezpieczeństwa, to jego ewoluowanie można wyjaśnić zbyt późnym podjęciem działań zmierzających do opanowania poważnego kryzysu zdrowotnego powiększającego się „w tempie wykładniczym”, który teraz wymaga reakcji w najpilniejszym trybie. Zagrożenie bezpośrednio wpływa na pokój i bezpieczeństwo, ponieważ dotyka państwa zaangażowane w proces mający na celu właśnie przywrócenie trwałego pokoju i bezpieczeństwa. Jak zauważył przedstawiciel Rwandy, Rada Bezpieczeństwa, która wspiera procesy pokojowe w tych trzech krajach, może się niepokoić jedynie o skutki epidemii eboli z punktu widzenia bezpieczeństwa.

Stanowisko Rady Bezpieczeństwa oraz kwalifikacja sytuacji przyjęta w celu stawienia czoła kryzysowi zwiąanemu z epidemia goraczki krwotocznej ebola, nawet jeśli z konieczności zostały przyjęte w trybie pilnym, to musza być oceniane w świetle postanowień Karty określajacych zakres uprawnień i obowiązków Rady. Z tego punktu widzenia można uznać, że „rewolucyjny” charakter stanowiska Rady wydaje się zniuansowany. Wpisuje się to w proces poszerzania stosowania pojęcia zagrożenia dla pokoju i bezpieczeństwa międzynarodowego, który miał swój początek jeszcze przed końcem zimnej wojny i wywołał wiele pytań. Jednak wydaje się, że w tym przypadku, w obliczu epidemii eboli, wykorzystanie tego pojęcia w celu uzasadnienia interwencji Rady Bezpieczeństwa nie mogło być kontestowane. Powszechnie wiadomo, że pojęcia międzynarodowego pokoju i bezpieczeństwa uległy głębokiej przemianie wobec perspektywy, z jaka mierzyli się autorzy Karty i która koncepcyjnie nie została zakwestionowana. Nie dotyczy to jednak ich możliwej instrumentalizacji przez Radę Bezpieczeństwa.

Pokojowi w jego wymiarze negatywnym, braku konfliktów zbrojnych, czy wręcz konfliktów zbrojnych między państwami, towarzyszy dziśs poszukiwanie pokoju w wymiarze pozytywnym, tzn. globalnego zjawiska odpowiadajacego pragnieniu porządku, a nawet więcej: „porządku społecznego”"11. Podczas gdy bezpieczeństwo państw i między państwami, zgodnie z postanowieniami Karty, pozostaje warunkiem koniecznym zapewnienia jednostkom bezpieczeństwa, to nie jest ono wystarczające i musi być uzupełniane poszukiwaniem bezpieczeństwa ludzi, które polega na ochronie ich przed takimi zagrożeniami jak ubóstwo, głód, przestępczość, łamanie praw człowieka, zagrożenia dla środowiska, handel ludźmi czy choroby ${ }^{12}$. Wobec tego, w świetle pokoju pozytywnego i bezpieczeństwa ludzi, gdzie oba pojęcia zawierają komponent zdrowotny, zagrożenia stały się wielowymiarowe, co 31 stycznia 1992 r. odnotowała

11 J.-M. Sorel, L'élargissement de la notion de menace contre la paix, w: Le Chapitre VII de la Charte des Nations Unies, Paris 1995, s. 16; zob. P. d'Argent et al., Article 39, w: J.-P. Cot, A. Pellet, M. Forteau (éd.), Commentaire de la Charte des Nations Unies article par article, $3^{\mathrm{e}}$ éd. Paris 2005, s. 1164.

12 Zob. C.-P. David, J.-F. Rioux, Le concept de sécurité humaine, w: J.-F. Rioux (éd.), La sécurité humaine, une nouvelle conception des relations internationales, Paris 2002, s. 19. 
Rada Bezpieczeństwa na posiedzeniu szefów państw i rządów. Potwierdzili to sekretarz generalny w Programie dla pokoju ${ }^{13}$ oraz Panel Wysokiego Szczebla ds. Zagrożeń, Wyzwań i Zmian: „każde wydarzenie lub zjawisko, które zabija lub zagraża przetrwaniu i podważa fundamenty państwa, jako podstawowego elementu systemu międzynarodowego, stanowi zagrożenie dla bezpieczeństwa międzynarodowego" ${ }^{14}$. Można z pewnością stwierdzić, odwołując się do ducha, jeśli nie do litery Karty, że od tamtej pory kryzysy zdrowotne stanowią zagrożenie dla międzynarodowego pokoju i bezpieczeństwa, uzasadniając tym samym działania podejmowane przez ONZ.

W ONZ to Rada Bezpieczeństwa, odpowiedzialna przede wszystkim za utrzymanie pokoju i bezpieczeństwo międzynarodowe, w rzeczywistości promowała lub nawet przyspieszyła tę przemianę. Zdecydowała bowiem, by włączyć do kategorii zagrożeń dla międzynarodowego pokoju i bezpieczeństwa „zagrożenia gospodarcze i społeczne”. Zrobiła to przez umieszczenie w porządku obrad kryzysu żywnościowego w Afryce, kwestii AIDS, związku między energia, bezpieczeństwem i klimatem oraz wpływu zmian klimatycznych na utrzymywanie pokoju. Instrumenty prawne, z których Rada korzysta, obejmują liczne elementy, od debaty podczas spotkań tematycznych, przez oświadczenia prezydencji, aż do rezolucji. Co istotne, w kwestiach zdrowotnych Rada Bezpieczeństwa wybrała formę rezolucji ${ }^{15}$.

Niewątpliwie Rezolucja nr 2177 (2014) jest częścią logiki, która usprawiedliwiłaby użycie przez Radę kwalifikacji zagrożenia międzynarodowego pokoju i bezpieczeństwa, by podjąć interwencję przeciwko epidemii eboli. O ile logika ta została jednak zakwestionowana, to szczególny charakter kontekstu, w którym przyjęto Rezolucję nr 2177 (2014), pozwala wyjść poza pytania, które jej tekst może wzbudzić, gdyż przyjęcie w niej kwalifikacji zagrożenia dla pokoju i bezpieczeństwa międzynarodowego nastapiło bez żadnego formalnego wyjaśnienia.

Daje tu znać o sobie częsta, o ile nie stała, praktyka Rady, która objawia się w dążeniu do potwierdzania, że realizuje w tym przypadku uprawnienia ściśle dla niej zastrzeżone, wyrażone w słynnej już formule, z której wynika, że ,zagrożenie pokoju w rozumieniu artykułu 39 to wyłącznie sytuacja, w której organ właściwy do podjęcia decyzji o sankcjach orzeka, że sytuacja ta jest rzeczywistym zagrożeniem dla pokoju"16. Nie ma zatem żadnych przeszkód, by Rada Bezpieczeństwa zdecydowała o zakwalifikowaniu epidemii eboli jako zagrożeniu dla pokoju. Wprawdzie uprawnienia te - bywa, że negatywnie oce-

${ }^{13}$ Zob. B. Boutros Ghali, Agenda pour la paix, UN Doc. A/47/277 (17 juin 1992).

${ }^{14}$ Zob. Rapport du groupe de personnalités de haut niveau sur les menaces, les défis et les changements, UN Doc. A/59/625 (2 décembre 2004) „2: parmi les six menaces qui guettent l'humanité aujourd'hui et dans les décennies à venir, le rapport relève les menaces d'ordre économique et social [...] dont les maladies infectieuses".

${ }^{15}$ Zob. rezolucja 1308 (2000) z 17 lipca 2000 référencée 'Responsabilité du maintien de la paix et de la sécurité internationale incombant au Conseil de sécurité: le VIH/ sida et les opérations internationales de maintien de la paix' et la résolution 1983 (2011) du 7 juin 2011 référencée 'Maintien de la paix et de la sécurité internationale'.

${ }^{16}$ J. Combacau, Le pouvoir de sanction de l'ONU. Etude théorique de la coercition non militaire, Paris 1974, s. 100. 
niane jako graniczące $\mathrm{z}$ arbitralnością i prowadzące do postrzegania spraw znajdujących się w międzynarodowej agendzie w sposób zbyt asekurancki nie podlegaja jednak zasadzie legibus solutus. Rada ma obowiąek respektowania Karty, której postanowieniami została powołana, a także podziału kompetencji i ustanowionej przez nią statutowej równowagi. Ponadto można przyjąć, że w prawie międzynarodowym także władza dyskrecjonalna ma swoje granice w oczywistym błędzie w ocenie. Powyższe kwestie nierzadko prowokowały do stawiania pytań, w żaden sposób nie podważają jednak znaczenia kwalifikacji przyjętej Rezolucją nr $2177(2014)^{17}$.

Kwestia ta może więc zmieniać miejsce w obszarze równowagi konstytucyjnej zawartej w Karcie, o ile weźmiemy pod uwagę korzystanie z nadanych uprawnień, bez stosowania przymusu, które może realizować zarówno Rada Bezpieczeństwa, jak i Zgromadzenie Ogólne. Podczas gdy na Radzie Bezpieczeństwa spoczywa główna odpowiedzialność za utrzymanie międzynarodowego pokoju i bezpieczeństwa, to Zgromadzenie Ogólne (art. 10) może omawiać „wszelkie zagadnienia lub sprawy wchodzące w zakres Karty”, co w sposób oczywisty obejmuje kwestie utrzymania pokoju. Zgodnie z art. 12 ust. 1 Zgromadzenie ma ograniczone kompetencje w wydawaniu zaleceń (ale nie do omawiania spraw) w sytuacji, gdy Rada Bezpieczeństwa wcześniej podjęła już działania, wykonując „funkcje powierzone jej przez niniejszą Kartę”. W ten sposób, w hipotetycznej sytuacji, oba organy realizowałyby swoje uprawnienia, które mogłyby okazać się konkurencyjne, ponieważ Rada nie działałaby, używajac śsodków przymusu, ale mogłaby mimo wszystko zablokować jakąkolwiek inicjatywę Zgromadzenia Ogólnego. Byłoby to możliwe, gdyby Rada zakwalifikowała jakieś zagrożenie, nawet wirtualne, jako zagrożenie dla pokoju i bezpieczeństwa międzynarodowego, wykonując tym samym, na podstawie czysto uznaniowej własnej oceny, „funkcje powierzone jej przez Kartę”. Zatem Rada, swobodnie stwierdzając istnienie zagrożeń, równie swobodnie określa zakres swoich funkcji i według własnego uznania ogranicza zakres funkcji Zgromadzenia Ogólnego.

Uwarunkowania, które czasami prowadzą do takich konstatacji, ujawniają obszary, w których proces ten mógłby być skrytykowany, a debaty na temat HIV/AIDS, a następnie zmian klimatycznych się skrystalizowały. Podczas prac nad przyjęciem Rezolucji nr 1308 (2000) wiele państw podkreślało, że to od Zgromadzenia Ogólnego, a właściwie Rady Gospodarczej i Społecznej, zależy walka z pandemią HIV/AIDS ${ }^{18}$. Wszystkie organy Organizacji Narodów Zjednoczonych są powołane do interweniowania, jednakże przy respektowaniu

${ }_{17}$ Zgodnie z art. 39 Karty NZ Rada może działać tylko w zakresie, w jakim stwierdza istnienie realnego, a nie wirtualnego zagrożenia. Zdroworozsądkowa interpretacja słowa "groźba” powinna skłonić Radę do podjęcia działań w perspektywie prewencyjnej, ale przedmiot zagrożenia musi być jednak bardzo realny. Rzeczywiście, jeśli przedmiot istnieje, zagrożenie również istnieje. Jeśli przedmiot jest możliwy, tak samo jest z zagrożeniem. Jednakże Rada nie może oprzeć swoich akcji na wirtualnym zagrożeniu, ryzykując zerwanie równowagi ustalonej przez Kartę, czy jest to kwestia równowagi między władzami państwowymi a uprawnieniami ONZ czy między Zgromadzeniem Ogólnym a Radą Bezpieczeństwa.

${ }_{18}$ Zob. H. de Pooter, Le droit international face aux pandémies: vers un système de sécurité sanitaire collective?, maszynopis doktoratu, Paris 2013, s. 199, przyp. 736. 
właściwego podziału zadań między nimi, a w szczególności między Zgromadzeniem Ogólnym i Radą Bezpieczeństwa, ponieważ wśród głównych obszarów odpowiedzialności Rady nie znajduje się walka z tą pandemia. Podczas debat nad wpływem zmian klimatycznych na utrzymywanie pokoju opinie w tej kwestii były formułowane jeszcze wyraźniej, a wręcz przyjęły formę zinstytucjonalizowaną. To wyjaśnia, przynajmniej częściowo, różnice poglądów, jakie wywołuje Rezolucja nr 2177 (2014).

Zmiana jest szczególnie widoczna w debatach, które doprowadziły do jej przyjęcia. Tylko jedno państwo, Argentyna, które często wykazuje nieufność wobec Rady, przedstawiło otwarcie nie tyle swój sprzeciw, ile niuanse dotyczące jej interwencji. Państwo to wskazało, że „inne organy systemu Narodów Zjednoczonych maja kompetencje do dogłębnego zbadania przyczyn i skutków tej epidemii, tzn. Zgromadzenie Ogólne, Rada Gospodarcza i Społeczna oraz wyspecjalizowane agencje, takie jak WHO"19. Podczas gdy na szczeblu międzynarodowym toczyła się gorąca debata dotycząca tego, które z tych organów mają odpowiednie kompetencje, by stawić czoła epidemii, kryzys niszczył strukturę dotkniętych nią społeczeństw, mogąc zrujnować osiagnięcia uzyskane w tych krajach dzięki międzynarodowym wysiłkom na rzecz budowania pokoju. W rezultacie pokój i bezpieczeństwo są poważnie zagrożone na poziomie krajowym, regionalnym i globalnym. Taka interpretacja może opierać się na swoistych cechach kontekstu, w którym interweniowała Rada i które wydają się usprawiedliwiać jej działanie. Po pierwsze, Rada podchodzi bezpośrednio do zagrożenia, na które zamierza zareagować, kwalifikujac je jako zagrożenie dla międzynarodowego pokoju i bezpieczeństwa, taka kwalifikacja nie pojawiła się w przypadku dwóch innych rezolucji dotyczacych kwestii zdrowia światowego. Tak poważne zagrożenie musi zatem pociagać za sobą nie działania w perspektywie średnio- lub długoterminowej, ale reakcję w trybie najwyższej konieczności. Rada Bezpieczeństwa pełni zatem rolę określoną przez Kartę nie tylko w obszarze bezpieczeństwa konwencjonalnego, ale także bezpieczeństwa „cywilnego”. Wobec konieczności natychmiastowych działań kwestia konkurencji ze Zgromadzeniem Ogólnym, którego kompetencje dotyczą utrzymania pokoju w jego wymiarze strukturalnym, jest nieaktualna ${ }^{20}$. Nie ma kwestii marginalizacji Zgromadzenia Ogólnego ani żadnej innej instytucji w systemie Narodów Zjednoczonych, jest natomiast dążenie do jak najskuteczniejszego podziału wypełnianych misji. Fakt, że 130 państw podpisało projekt rezolucji, potwierdza, że myśl zawarta w jej treści daleko wykracza poza ścisły krag członków Rady, a tym bardziej poza krag jej stałych członków.

Nie pozostaje to bez wpływu na ocenę, jaką można sformułować w sprawie wykonywania przez Radę swoich uprawnień dyskrecjonalnych. Mówiąc ogólniej, państwa te manifestowały obawy często wyrażane przeciwko dyskrecjonalnej władzy graniczącej z arbitralnością potężnej, ale kapryśnej Rady,

19 Zob. Oświadczenie przedstawiciela Argentyny, UN Doc. S/PV.7268 (n 11) 23.

${ }^{20}$ Według P.-M. Dupuy, Après la guerre du golfe, „Revue Générale de Droit International Public” 95, 1991, s. 623-624. 
działającej zgodnie z nieprzejrzystymi procedurami zdominowanymi przez jej stałych członków, zwłaszcza państwa zachodnie. Tę krytykę można dość łatwo odrzucić, ponieważ Rada rzeczywiście postawiła się w sytuacji kompetencji wiazanej: decyzja nie wynika z jej własnej oceny, lecz z ustaleń ekspertów WHO i organizacji pozarządowych, takich jak przede wszystkim Lekarze bez Granic. Rada przyjmuje to ustalenie i kwalifikuje sytuację jako zagrożenie dla pokoju i bezpieczeństwa międzynarodowego. W tym punkcie chodzi o korzystanie z uprawnień dyskrecjonalnych.

Dyskrecjonalne uprawnienia Rady Bezpieczeństwa nie mogą być jednak oceniane bez uwzględnienia przyjętych przez nią środków lub operacji, na których przeprowadzenie wydała zgodę. Analizowana z punktu widzenia wdrożonych środków Rezolucja nr 2177 (2014) okazuje się po raz kolejny mniej rewolucyjna, niż się wydawało. Rada Bezpieczeństwa wykorzystuje wszystkie możliwości działania, które jej zapewnia system bezpieczeństwa zbiorowego, jednakże dostosowuje je do powagi sytuacji stanowiącej dla niego zagrożenie. Czy jednak jest to nadal proste przystosowanie systemu bezpieczeństwa zbiorowego czy już prawdziwa innowacja, a Rada Bezpieczeństwa stara się przedstawić jako deus ex machina zarządzania globalnego?21

\section{ZASTOSOWANIE INSTRUMENTÓW BEZPIECZEŃSTWA ZBIOROWEGO W CELU ZWALCZANIA EPIDEMII EBOLI W AFRYCE}

Oprócz wyłącznego prawa Rady do stwierdzenia istnienia zagrożenia dla pokoju i bezpieczeństwa, dysponuje ona również, wynikającym z Karty, dyskrecjonalnym uprawnieniem wyboru form działania. Jest ich wiele, poczynając od łagodnych po najbardziej zdecydowane, stanowiące wręcz środki przymusu. Zgodnie z art. 39 Rada może „udzielać zaleceń” lub „decydować, jakie środki należy zastosować”, decyzja wydaje się jednak bardziej „typowa” dla bezpieczeństwa zbiorowego, bez rozróżnienia będącego wynikiem treści podjętego środka: zalecenie może zatem służyć, jako podstawa do działań zbrojnych. Należy przede wszystkim zauważyć, że sformułowania użyte przez Radę Bezpieczeństwa w Rezolucji nr 2177 (2014) w pełni wykorzystuja, a nawet wykraczaja poza możliwości, jakie daje art. 39. Najczęściej bowiem Rada „zachęca”, ale również „wnioskuje”, „zobowiązuje”, „prosi”, czyli stosuje wszystkie sformułowania, które wydają się wykluczać jakikolwiek obowiązkowy zakres przewidywanych środków. Przyjęte rozwiązanie wydaje się logiczne. W takim kontekście obowiązek wydaje się niewłaściwy, a środki przymusu niepociągaja za sobą użycia siły zbrojnej, co określa art. 41, a nawet więcej, środki obejmujące operacje sił zbrojnych przewidziane w art. 42 wydaja się „mało sensowne”. Nie można jednak wykluczyć, że w wyniku przejścia od zalecenia

${ }_{21}$ Zob. R. Kolb, Le droit relatif au maintien de la paix et de la sécurité internationales, évolution historique, valeurs fondatrices et tendances actuelles, Paris 2005, s. 42. 
do decyzji Rada użyje tego uprawnienia w kwestiach merytorycznych, takich jak wniosek skierowany do państw o zastosowanie protokołów bezpieczeństwa i ochrony zdrowia lub „zniesienie ograniczeń dotyczacych przemieszczania się i granic nałożonych z powodu epidemii eboli”. Ta ostatnia kwestia wydaje się szczególnie wrażliwa na tyle, na ile ograniczenia zostały rzeczywiście wprowadzone przez państwa, które nie są bezpośrednio dotknięte epidemią ${ }^{22}$. W innych okolicznościach Rada Bezpieczeństwa, powołując się na zakres decyzji wydanych na podstawie artykułu 25 Karty, mogła zignorować wszelkie sprzeciwy ze strony państw wobec nałożenia międzynarodowych zobowiązań przez rezolucje podjęte na podstawie rozdziału VII Karty ${ }^{23}$. Czy mogła zastosować Rezolucję nr 2177 (2014) w celu wymuszenia poszanowania zapisów MPZ? W takim przypadku trudniej byłoby zarzucać jej wchodzenie w rolę międzynarodowego legislatora, ponieważ rezolucja miałaby ograniczony zakres w czasie i przestrzeni ${ }^{24}$.

Stanowiska kilku organizacji międzynarodowych, oprócz WHO, mogły również zachęcić ją do działania w tym kierunku. Na przykład Międzynarodowa Organizacja Lotnictwa Cywilnego podkreśliła, że „kraje, których epidemia nie dotknęła, powinny unikać podejmowania działań, które niepotrzebnie utrudniłyby międzynarodowe podróże lub handel" ${ }^{25}$. Podobnie Rada Wykonawcza Unii Afrykańskiej na swym posiedzeniu 8 września wezwała państwa afrykańskie do zniesienia wszystkich ograniczeń podróży. Niemniej Rada Bezpieczeństwa, która uczyniła już pierwszy krok w sprawie kwalifikacji, z pewnością nie mogła na tym etapie pójść dalej w kwestii uprawnień, które była gotowa wykorzystać do takiej kwalifikacji. W działaniach operacyjnych prowadzonych przeciwko wirusowi ebola Rada Bezpieczeństwa odwołała się do konwencjonalnych instrumentów, którymi dysponuje w ramach utrzymywania pokoju: z jednej strony zabiega o podjęcie działań i kieruje działaniami państw i organizacji międzynarodowych, z drugiej strony przyczynia się do zorganizowania opera-

${ }^{22}$ Państwa zachodnie, jak Australia i Kanada, zawiesiły „rozpatrywanie wniosków złożonych przez cudzoziemców, którzy fizycznie przebywali w kraju wskazanym przez WHO. Działania te mają na celu ograniczenie rozprzestrzeniania się choroby na dużą skalę. Jednakże postawa ta została potępiona i uznana za nieskuteczną (a nawet przynosząca skutki odwrotne do zamierzonych) przez WHO i wszystkich pracowników medycznych w terenie. Poza tym zostało to uznane za naruszenie międzynarodowych przepisów zdrowotnych, których celem jest zapobieganie rozprzestrzenianiu się chorób przez proporcjonalne działania ograniczające ryzyko dla zdrowia publicznego. Tak też było z tymczasowym zaleceniem przyjętym przez WHO na podstawie RSI (2005) z 29 kwietnia 2009 r., w którym państwa zdecydowały się wyjść poza zalecenia, przedstawiając naukowe uzasadnienie swojej decyzji. Widać, że państwa, które nie przestrzegają zobowiązań wynikających z prawa międzynarodowego, mogły utrudnić działanie Rady Bezpieczeństwa w obliczu zagrożenia dla międzynarodowego pokoju i bezpieczeństwa.

${ }^{23}$ Zob. P.-M. Dupuy, Y. Kerbrat, Droit international public, $12^{\mathrm{e}}$ éd, Dalloz 2014, s. 682, rezolucja 1373 (2001) jest godnym uwagi instrumentem, ponieważ stanowi prawdziwy program działań przeciwko terroryzmowi, wiążący wszystkie państwa członkowskie; szerzej na ten temat zob. $\mathrm{S}$. Szurek, La lutte internationale contre le terrorisme sous l'empire du Chapitre VII un laboratoire normatif, „Revue Générale de Droit International Public” 109, 2005, s. 17.

${ }^{24}$ Zob. L. Condorelli, Les attentats du 11 septembre 2011 et leurs suites: où va le droit international?, „Revue Générale de Droit International Publics” 105, 2001, s. 834.

${ }^{25}$ Zob. OACI, Déclaration sur les voyages et les transports en rapport avec l'épidémie de maladie à virus Ebola (18 août 2014). 
cji utrzymania pokoju. Po raz kolejny nietypowość zagrożenia ma bezpośredni wpływ na te różne sposoby działania.

Porządek zachowany w uchwale jest znaczacy: odsyła do tego, kto zarządza realizacją obowiązku ochrony. To przede wszystkim państwa dotknięte epidemia, a zwłaszcza te, które zwróciły się do organizacji o podjęcie działań w celu ochrony swojej ludności. Rada zaleca im działania w zakresie zdrowia, określając sposób ich wdrożenia, ale także w obszarze społeczno-gospodarczym, humanitarnym i bezpieczeństwa. Poza zniesieniem ograniczeń w podróżowaniu Rada wystapiła także do państw trzecich o zapewnienie wsparcia i pomocy państwom dotkniętym epidemią przez podjęcie niezbędnych działań mających na celu zapobieżenie rozprzestrzenianiu się choroby. Rada zdecydowała się także, w sposób klasyczny, na oparcie się na organizacjach międzynarodowych, a przede wszystkim na organizacjach regionalnych, których sytuacja bezpośrednio dotyczy, sugerując - bez powołania się na Kartę - podział zadań nieróżniący się od tego, o którym mowa w jej rozdziale VIII. Rzeczywiście, zauważmy, że Unia Afrykańska na poziomie operacyjnym interweniowała w sposób szczególnie zdeterminowany w obliczu zagrożenia, jeszcze zanim zareagował system Narodów Zjednoczonych. Już 19 sierpnia 2014 r. Rada Pokoju i Bezpieczeństwa podjęła decyzję o utworzeniu „mieszanej cywilnej i wojskowej misji medycznej i humanitarnej Unii Afrykańskiej złożonej z lekarzy, pielęgniarek i innego personelu medycznego i paramedycznego, a także z personelu wojskowego niezbędnego do ochrony i zapewnienia skuteczności misji”. W takim systemie inne organizacje regionalne, w szczególności Unia Europejska, interweniuja, tak jak w większości operacji pokojowych w Afryce, dając wsparcie dla działań organizacji afrykańskich.

System ONZ również wykorzystał technikę operacji pokojowych przez utworzenie Misji Organizacji Narodów Zjednoczonych ds. natychmiastowej pomocy w kwestii eboli (UNMEER), a także przez mobilizację istniejaccych operacji. Powołanie UNMEER nie wynika z Rezolucji nr 2177 (2014), ale z decyzji Rady Bezpieczeństwa i sekretarza generalnego, który - podobnie jak Zgromadzenie Ogólne - został wezwany do poparcia tej inicjatywy ${ }^{26}$.

Zasadniczym zadaniem Misji jest koordynacja działań wszystkich podmiotów w terenie: agencji ONZ, wyspecjalizowanych agencji, organizacji regionalnych, państw, organizacji pozarządowych i innych zainteresowanych stron, by uniknąć powielania działań i zapewnić ich skuteczność. Ponadto działa jako jednostka zarządzająca kryzysem, której zadaniem jest zapewnienie ogólnego podejścia i stworzenie kompleksowego planu działania. UNMEER wyjątkowy jest także ze względu na swój skład. Ma swoją siedzibę w Akrze, ale działa operacyjnie na terenie trzech najbardziej dotkniętych państw, skupia około 100 „zwerbowanych z całego świata” funkcjonariuszy ONZ, wyspecjalizowanych agencji i państw członkowskich, angażując kadry zarówno cywilne, jak i woj-

${ }^{26}$ Misja ta, pierwsza tego rodzaju, według Sekretariatu Generalnego możliwa do powtórzenia, jest wyjątkowa z więcej niż jednego powodu. Po pierwsze, nie jest misją wojskową ani policyjna, lecz ratunkową misją medyczną ONZ pod auspicjami sekretarza generalnego i kierowana przez jego specjalnego przedstawiciela. Po drugie, dla UNMEER ustalono sześć strategicznych celów związanych ze zwalczaniem wirusa ebola. 
skowe. Misja szybko również zmobilizowała znaczne środki logistyczne, dzięki temu, że sekretarz generalny zniósł ograniczenia administracyjne i księgowe, aby poradzić sobie z sytuacja kryzysowa.

Uruchamiano również klasyczne misje pokojowe działające na tym obszarze, zwłaszcza te już działające w państwach dotkniętych epidemią. Tak było w przypadku misji Organizacji Narodów Zjednoczonych w Liberii (UNMIL), powołanej Rezolucją nr 1509 z 19 września 2003 r., zaangażowanej w proces umacniania pokoju i bezpieczeństwa, która otrzymała nowe obowiązki, by wraz z liberyjskimi instytucjami zajmującymi się bezpieczeństwem zaplanować operacje konieczne w sytuacji nadzwyczajnego zagrożenia zdrowia. Misje działające na Wybrzeżu Kości Słoniowej (UNOCI) i w Mali (MINUSMA), bez modyfikowania ich mandatów, przyjęły do realizacji - we współpracy z UNMEER - zadania niezbędne dla niedopuszczenia do pojawienia się epidemii w tych krajach i zapewnienia ciagłości swych misji.

Wykorzystanie instrumentów pokojowych dostosowanych do zwalczania epidemii eboli znajduje swoje potwierdzenie w obecności i warunkach użycia sił wojskowych. Podczas gdy połączenie działań wojskowych i humanitarnych bywało często potępiane, w tym przypadku interwencji wojskowej domagały się niektóre organizacje pozarządowe, ponieważ wojsko okazało się jedyna siła, która mogła w trybie natychmiastowym uruchomić działania logistyczne tak rozległe, jak wymagała tego sytuacja spowodowana epidemią. Jednakże w przypadku misji ONZ, organizacji regionalnych czy inicjatywy podejmowane przez państwa członkowskie wojsko jest tu jedynie instrumentem w akcjach dotyczących zdrowia.

\section{MIĘDZY BEZPIECZEŃSTWEM ZBIOROWYM A ZARZĄDZANIEM GLOBALNYM}

Operacja Rady Bezpieczeństwa przeciw epidemii eboli wydaje się zatem ambiwalentna. Rada działała na podstawach systemu bezpieczeństwa zbiorowego i użyła instrumentów dostarczonych przez ten system w celu przeprowadzenia akcji, która nieco odbiega od jej tradycyjnej roli. Oznacza to, że w tym przypadku jej rola nie była ani rolą policjanta, jak przewidziano w Karcie, ani legislatora, do czego czasem rości sobie prawo ${ }^{27}$.

Państwa, które podjęły działania, miały za zadanie ostrzegać, mobilizować i koordynować, jednakże włącznie Rady Bezpieczeństwa do akcji, ze względu na nadzwyczajnie pilny charakter sytuacji, miało na celu zapewnić taką potrójną misję. Kwestia ta podniesiona na taki szczebel „skorzystała” na zaangażowaniu Rady dzięki nagłośnieniu sytuacji nieporównywalnie większym, niż gdyby interwencję podjęło Zgromadzenie Ogólne. Sprawa uległa także dramatyzacji, gdyż Rada jest organem, który zazwyczaj angażuje się w sprawy wojny

${ }^{27}$ Szerzej zob. Karta Narodów Zjednoczonych z 26 czerwca 1945 r., Dz. U. 1947, Nr 23, poz. 90 ze zm.; L. Kasprzyk, Rozwój ekonomiczny - nadzieja na wyrównanie szans, w: J. Symonides (red.), Organizacja Narodów Zjednoczonych. Bilans i perspektywy, Warszawa 2006, s. 245-261. 
lub pokoju. Akcji pomógł autorytet ze względu na uprawnienie Rady Bezpieczeństwa do przyjmowania aktów mających charakter obowiązujący czy wręcz przymusowy. Do tego dodać należy korzyść wynikającą z umocowania, organ ten działa bowiem, zgodnie z artykułem 24 ust. 1 Karty, w imieniu wszystkich państw członkowskich. W tej roli Rada działała w idei bezpieczeństwa zbiorowego, którego celem jest zapewnienie wszystkim bezpieczeństwa poprzez działania wszystkich ${ }^{28}$. Sposoby jej działań sa od tego jednak odległe: Rada musi rozwijać się nie w stronę struktury hierarchicznej, lecz struktury sieci. Lista możliwych do zmobilizowania aktorów jest nieokreślona, bez względu na ich status prawny: dotyczy to w szczególności organizacji pozarządowych, prywatnych fundacji, a także przedsiębiorstw. Rada Bezpieczeństwa powinna więc przymus i regulacje na zasadzie hard law zastapić perswazja.

Wyróżniono tutaj niektóre cechy zarządzania, a dokładniej: tzw. zarządzanie globalne ${ }^{29}$. Niezależnie od watpliwości koncepcyjnych związanych z tymi pojęciami Organizacja Narodów Zjednoczonych logicznie przyznała sobie prawo do zarządzania globalnego, ponieważ „pozostaje jedynym forum, na którym można rozwiązywać problemy ogólne przy wsparciu wszystkich aktorów społeczności międzynarodowej”. W rezultacie oczekuje się, że wszystkie organy ONZ staną się stronami zainteresowanymi zarządzaniem globalnym.

Przypadek Rady Bezpieczeństwa jest jednak szczególny, ponieważ Karta nadała jej swoistą misję w obszarze bezpieczeństwa zbiorowego. Rada, opierając się na ewolucji tego systemu i konwergencji, która przejawia się w zarządzaniu globalnym, łączy te dwie funkcje (zagwarantowanie bezpieczeństwa zbiorowego i sterowanie zarządzaniem globalnym $)^{30}$. Z tego punktu widzenia Rezolucja nr 2177 (2014) stanowi zatem szczególnie istotny krok. Jednakże, jak pokazał Arcari, istnieja „elementy dysonansu” między bezpieczeństwem zbiorowym a zarządzaniem globalnym, prowadzace do kwestionowania nie zasadności, ale skuteczności prac Rady Bezpieczeństwa w tym obszarze.

Zatem, aby zwalczyć epidemię, zarządzanie globalne musi być realizowane w dłuższej perspektywie, a wręcz mieć charakter długotrwały: celem jest utworzenie lub usprawnienie krajowych systemów opieki zdrowotnej, które albo nie istnieja, albo zawodza, a dokonać tego można, wdrażając odpowiednią politykę rozwoju. Przy czym nie ma tu mowy o zwyczajowym sposobie działania, wymuszonym najczęściej przez nadzwyczaj pilne sytuacje, a nie wydaje się, by te występowały już w takiej samej ostrości w większości państw. Ponadto reakcja Rady Bezpieczeństwa w obliczu epidemii jest również wynikiem postawy redukującej, skłaniającej do rozwiązywania problemów międzynarodowych przez ich rzeczywisty lub postrzegany wymiar bezpieczeństwa.

${ }^{28}$ J. Salmon definiuje zbiorowe bezpieczeństwo jako fakt, że „każdy może odnieść korzyści w postaci wspólnych działań, gwarancji dla całej społeczności”, Dictionnaire de droit international public, Bruxelles 2001, s. 1024.

${ }_{29}$ Zob. J.-M. Moreau-Defarges, La gouvernance, Paris 2003; zob: J.-L. Dunoff, J.-P. Trachtman (eds.), Ruling the World? Constitutionnalism, International Law and Global Governance, Cambridge 2009, a szczególnie w aspekcie prawnym: M. Kamto, Droit international de la gouvernance, Paris 2013.

${ }^{30} \mathrm{~L}$. Balmond, Gouvernance globale et sécurité collective, les profils d'une convergence, w: M. Arcari, L. Balmond, op. cit., s. 3-22. 


\section{ZAKOŃCZENIE}

Pytanie postawione $\mathrm{w}$ niniejszym artykule dotyczyło tego, czy walka z pandemiami, która - hipotetycznie - zmusza do szukania równowagi między bezpieczeństwem państwa a wolnym handlem, przybiera formę „zbiorowego systemu bezpieczeństwa zdrowotnego". Wychodzac od tradycyjnej definicji bezpieczeństwa zbiorowego, przeniesionej przez analogię na przypadki pandemii, stawiamy sobie pytanie, czy w zamian za rezygnację z prawa do stosowania jednostronnych środków sanitarnych, znacząco naruszających swobodę wymiany handlowej, każde państwo może korzystać z gwarancji wspólnoty w postaci wspólnych działań kierowanych przez organy międzynarodowe w sytuacji zagrożenia rozprzestrzenianiem się choroby zakaźnej w ten sposób, by system zbiorowego bezpieczeństwa zdrowotnego nie naruszał prawa państw do stosowania indywidualnych środków niezbędnych do ochrony zdrowia na ich terytorium.

$\mathrm{Z}$ analizy problematyki przestawionej $\mathrm{w}$ niniejszym tekście wynika, że w przypadku walki z epidemiami mamy do czynienia z elementami „zbiorowego systemu bezpieczeństwa zdrowotnego". Elementy te to formy wspólnych działań kierowanych przez organizacje i instytucje międzynarodowe, w ramach których każde państwo może korzystać ze wsparcia społeczności międzynarodowej ${ }^{31}$. Konieczność takiego współdziałania spowodowana jest przede wszystkim transgranicznym charakterem zagrożenia pandemicznego i stawia państwa w sytuacji współzależności. W ten sposób państwa ukształtowały uniwersalny system zbiorowego bezpieczeństwa zdrowotnego zawarty w Międzynarodowych przepisach zdrowotnych. Zasadniczo twierdzić można, że zarówno w przypadku walki z epidemią eboli, jak i wcześniejszymi epidemiami mieliśmy raczej do czynienia z mechanizmem globalnego zarządzania kryzysem, aniżeli faktycznym ukształtowaniem się systemu bezpieczeństwa zdrowotnego. Jak podkreśla Jan Sandorski, z dotychczasowych rozważań można by wyciagnąć błędny wniosek, że walka międzynarodowej społeczności z pandemią toczy się jedynie w krajach politycznego Południa ${ }^{32}$.

dr Boubacar Sidi Diallo

Uniwersytet im. Adama Mickiewicza w Poznaniu

diallo@amu.edu.pl

${ }^{31}$ Zob. A.D. Rotfeld, The Role of the International Community, w: M.F. Plattner, A. Smolar (eds.), Globalisation, Power and Democracy, Baltimore-London 2000, s. 83-96.

${ }^{32}$ Szerzej na ten temat zob. J. Sandorski, Międzynarodowa ochrona praw człowieka a HIV/ AIDS, Poznań 2002; E. Karska (red.), Globalne problemy ochrony praw człowieka, Warszawa 2015. 


\section{THE EBOLA PANDEMIC AS A THREAT TO INTERNATIONAL PEACE AND SECURITY: A QUESTION OF COLLECTIVE SECURITY OR GLOBAL GOVERNANCE?}

\section{Sum mary}

The international community faces a fragmented and transnational epidemiological threat, the severity and extent of which currently require an unprecedented level of intervention. Over the centuries, mankind has been confronted with a variety of epidemics that have always required a comprehensive action at the international level. According to the UN Security Council, the outbreak of the Ebola virus at the end of 2013 poses a particular threat to international peace and security, as the peace-building and development achievements of the countries most affected by the epidemic are jeopardised and may end in vain or be lost altogether. This in turn undermines the stability of the countries most affected. If the disease is not brought under control, this situation might lead to a new unrest and social tensions, and worsening of the political climate, or stigmatisation and a higher sense of uncertainty in the region. The resolution adopted by the UN Security Council on this matter has a historic dimension, as it has for the first time classified a public health problem as a threat to international peace and security. This happened despite the fact that international mobilisation had been delayed by several months, despite the obvious urgent need for action. 
